\title{
СУЩНОСТЬ И ФУНКЦИИ РЕЕСТРОВОЙ ДЕЯТЕЛЬНОСТИ В ТУРИЗМЕ В УСЛОВИЯХ ЦИФРОВОЙ ЭКОНОМИКИ: ЭКОНОМИКО-ПРАВОВОЙ АСПЕКТ ${ }^{1}$
}

\section{THE ESSENCE AND FUNCTIONS OF TOURISM REGISTER ACTIVITY IN ITHE DIGITAL ECONOMY: ECONOMIC AND LEGAL ASPECT}

V. Zolotovskiy

Summary. The purpose of this paper is to reveal the current practice of legal regulation and systematization of tourism activities in the aspect of analyzing the territories tourist potential, as well as identifying the specifics of the information forms system and means of developing the tourism industry in the Russian Federation. The characteristics of systematization practice allowed us to identify the goals and essential content of the relevant practice in the field of tourism promotion through information support, as well as in the field of protecting the business and consumer interests of participants in tourist activities. of particular importance is the fact that an imperative normative definition of the structure and content of these forms has been introduced in relation to registers aimed at ensuring the security of tourist relations in general, including private and public interests. At the same time, special forms of systematization introduced into tourist marketing as a comprehensive means of promoting Russian tourist products are implemented structurally and compositionally, taking into account the need to popularize tourist territories on the basis of the principle of attractiveness and the tasks of the national marketplace.

Keywords: tourist registers, systematization in tourism; legal regulation in tourism, marketing technologies, promotion in tourism, digital technologies in tourism.

\author{
Золотовский Владимир Алексеевич \\ Федеральное государственное автономное \\ образовательное учреждение высшего образования \\ «Волгоградский государственный университет» \\ zolotovskiy.azi@volsu.ru
}

Аннотация. Целью нашей статьи является раскрытие актуальной практики правового регулирования и систематизационной деятельности в туризме в аспекте анализа туристского потенциала территорий, а также выявления специфики системы информационных форм и средств развития туристской индустрии в РФ. Характеристика систематизационной практики в зависимости от субъекта позволили выделить цели и сущностное содержание соответствующей практики в сфере популяризации туризма посредством информационного обеспечения, а также в сфере защиты предпринимательских и потребительских интересов участников туристской деятельности. Особое значение имеет то, что императивное нормативное определение структуры и содержания этих форм введено относительно реестров, направленных на обеспечение безопасности туристских отношений в целом, включая частные и публичные интересы. Вместе с тем специальные формы систематизации, введенные в туристский маркетинг как комплексные средства продвижения российского турпродукта, реализуются структурно и композиционно с учетом необходимости популяризации туристских территорий на основе принципа аттрактивности и задач национального маркетплейса.

Ключевые слова: туристские реестры, систематизация в туризме; правовое регулирование в туризме, маркетинговые технологии, продвижение в туризме, цифровые технологии в туризме. ифровизация экономики и социальной сферы обусловили изменения в индустрии туризма и гостеприимства. Межотраслевой характер хозяйтвенной деятельности в сфере туристских услуг усиливают мультипликативный эффект и обусловливают неуклонный рост роли туризма в мировой экономике. В стабильных социально-экономических условиях, до кризиса рынка услуг, вызванного пандемией Covid-19, туристская индустрия являлась одной из са- мых высокодоходных отраслей в мировой экономике. Выступая в качестве одного из наиболее динамично развивающегося системного межотраслевого явления, туризм как никакая иная сфера деятельности объединяет в себе развивающиеся инструменты цифровизации.

В контексте решения макроэкономических задач в туризме необходимы различные предельно широ-

' Исследование выполнено при финансовой поддержке РФФИ и Администрации Волгоградской области в рамках научного проекта № 19-

49-340007 p_a 
кие информационные ресурсы. Именно в этой связи, в борьбе за первенство на международном рынке туристских услуг, национальные администрации в туризме и иные органы государственного управления уделяют особое внимание учету и систематизации, а также популяризации туристских ресурсов.

В контексте решения макроэкономических задач в туризме необходимы различные предельно широкие информационные ресурсы. Именно в этой связи в борьбе за первенство на туристском рынке государство выступает в роли одного из участников отношений, направляя свое внимание на учет и систематизацию, а также распространение информации и популяризацию туристских ресурсов.

Необходимо учитывать, что каждая из задач систематизационной практики имеет конкретную и вполне определенную цель. В частности, учет и реестровая деятельность, как составные виды систематизации, позволяют не только обеспечить статистический учет состояния туристской индустрии и характер использования ресурсов. Они являются основой для выбора стратегии, а также разработки программ развития туристской отрасли в целом. Столь же продуктивно они могут применяться с теми же целями на микроэкономическом уровне, при выборе маркетинговой стратегии туристского предприятия.

На сегодняшний день в условиях растущей конкуренции на туристском рынке вопросы эффективного учета в сфере туризма, актуализируется в аспекте информирования туристов (9, С. 217; 10; 36; 50; 52). Особое внимание исследователей привлекают вопросы о роли реестровой деятельности в развитии туризма конкретных регионов, а также в формировании условий устойчивого развития туризма $(51 ; 53 ; 54)$. Кроме того сохраняет дискуссионность проблема сущности реестровой деятельности, в рассмотрении которой, ученые нередко ограничивают исследовательское поле вопросами статуса материального объекта систематизации туристских ресурсов. Так, по мнению В.Б. Жарникова и А.В. Коневой основная задача реестровой практики В туристской деятельности идентична целям кадастрового учета объектов и форм собственности. Такой ограничительный подход явно находится под влиянием исследовательского поля туристско-рекреационной географии (5).

Аналогичное понимание отражено в работе Е.О. Ушаковой и М.Е. Цой, понимающих систематизацию туристских ресурсов как результат оценки потенциала $(42$, С. 24). Оценивая эффективность форм систематизации, исследователи подчеркивают минимальную информативность реестров и отдают предпочтение кадастрам (42, С. 24-25). Очевидно, что такой подход к оценке роли систематизации и содержания форм ее выражения противоречит устоявшейся теории и практики определения туристского потенциала территории $(15$, C. $217 ; 2$, С. $24 ; 41$, С. 57).

Целью нашей статьи является раскрытие актуальной практики правового регулирования и систематизационной деятельности в туризме в аспекте анализа туристского потенциала территорий, а также выявления специфики системы информационных форм и средств развития туристской индустрии в РФ.

Переходя к рассмотрению темы, остановимся на конкретизации предмета исследования. В рамках туристской политики национальной администрации в различных формах реализуются конкретные виды властной практики. Ее направления определяются потенциалом национальных туристских территорий. Безусловно, прямая связь ресурсной базы со стратегическими мероприятиями и целями туристской политики обусловливает развитие систематизационной практики в сфере туризма.

Несмотря на объективную актуальность вопрос институциональной систематизационной деятельности в туризме не находит должной реализации в муниципальной и государственной практике. Очевидно, это вызвано неопределенностью в государственном понимании функционального назначения систематизации туристских ресурсов и, как следствие, в бессистемном и по существу в общем и декларативном характере правового регулирования реестровой практики в России в сфере туризма. Прежде чем перейти к анализу систематизационной практики и форме ее нормативно-правового регулирования, определим субъектов систематизации, механизм ее реализации, а также, собственно приоритетные формы изучаемой практики.

Характеризуя систематизацию как форму учета туристских ресурсов (в самом широком смысле, т.е. включая и объекты туриндустрии), можно с уверенностью указать, что ее приоритетными деятельностными задачами являются учет и популяризация. Учет - осуществляется публичными субъектами с задачей сбора статистической информации, первичной характеристики туристского региона, первичной оценки его потенциала, определения экологической емкости туристской территории и экологической нагрузки на туристскую территорию, разработки программно-плановой документации, разработки мастер-плана и плана развития туристской территории (32), развития туристкой инфраструктуры.

Безусловно, публичные субъекты руководствуются специальными задачами систематизации, обу- 
словленными местом туризма в институциональной системе управления. Соответствующая компетенция и стратегическая цель каждого такого субъекта определяют форму и средства систематизационной практики. В частности, для субъектов федерального уровня исходя из цели регулирования турдеятельности, определенной федеральным законом Ф3 № 132 «Об основах туристкой деятельности в Российской Федерации», приоритетными являются: «обеспечение права граждан на отдых, свободу передвижения и иных прав при совершении путешествий; охрана окружающей среды; развитие туристской индустрии, обеспечивающей потребности граждан при совершении путешествий, создание новых рабочих мест, увеличение доходов государства и граждан Российской Федерации, развитие международных контактов, сохранение объектов туристского показа, рациональное использование природного и культурного наследия» $(48$, ст. 4). Отметим, что связь учетно-систематизационной практики соответствующих субъектов федерального уровня с безопасностью туристов обусловила приоритет цифровой формы систематизации.

В частности, выраженные в форме государственных услуг, вопросы безопасности туристов определили появление в цифровой форме таких реестров как ЕФРТ, реестр турагентов $(30 ; 47)$, реестр Ассоциации турпомощь, а также на протяжении многих лет находящийся в статусе «перспективного» проект цифрового реестра услуг (электронная путевка) - единой информационной системы электронных путевок (48, ст. 10.3; 21$)$.

Содержательная часть систематизации и уровень функционального наполнения ее механизма, ориентированного на развитие туристского рынка и создание условий для реализации туристского потенциала территорий, существенно выше в субъектах РФ. Очевидно в этой связи систематизационная деятельность получила наибольшее развитие и соответствующий набор правовых средств регулирования именно на уровне регионов. Прежде всего, это нашло выражение в нормативном обеспечении, воплощенного в форме субъектного законотворчества и региональных программ развития туризма.

Надо отметить, что субъектами России обеспечивается не только учетная функция систематизации, но и популяризационная. Именно в этой связи стандартные учетные формы систематизации туристских ресурсов регионов, как и на федеральном уровне, но с иными целями, распространяются в доступной цифровой форме.

Вторая группа субъектов систематизации имеет непубличную природу. Прежде всего речь идет о много- численных участниках отношений по формированию, продвижению и реализации турпродукта и единичных туристских услуг. В силу специфики целей деятельности этих субъектов их участие в той или иной форме систематизации в туризме ориентировано на позиционирование. Прежде всего речь идет о распространении информации о них самих, об услугах и объектах притяжения туристского интереса. Кроме того особое значение имеют формы систематизации направленные на создание условий для установления партнерских отношений, в том числе с публичными участниками как на уровне одного субъекта РФ, так и на межрегиональном уровне.

Регулирование реестровой деятельности публичных субъектов, направленной на обеспечение функции по сохранению экологических и историко-культурных ресурсов, нашло выражение в соответствующем федеральном законодательстве $(44 ; 46 ; 47)$. Акцентируя на аттрактивности и особой роли историко-культурных объектов в туристской практике отметим, что уже в первую редакцию федерального закона «Об объектах культурного наследия (памятниках истории и культуры) народов Российской Федерации» вошла новелла, согласно которой в специальную учетную практику вводился институт «Единого государственного реестра объектов культурного наследия народов Российской Федерации». Согласно ст. 15 этот реестр был создан и функционирует как «информационная система, обеспечивающая информационно-технологическое взаимодействие информационных систем, используемых для предоставления государственных и муниципальных услуг в электронной форме».

Информация об объектах культурного наследия и их территориях, содержащаяся в реестре, направлена на решение двух ключевых задач: а) популяризация культурно-исторического наследия РФ, а также обеспечение доступности информации об объектах; б) информационное обеспечение защиты и сохранности объектов культурного наследия.

Очевидно, что решение первой задачи прямо относится к туризму. В этой связи следует отметить, что благодаря функционированию Единого реестра объектов культурного наследия в особом цифровом режиме (35), размещенная в открытых данных информация не только упрощает туроперейтинг, но и повышает интерес самодеятельного туриста к регионам страны. Особое значение имеет информация в паспортах объектов памятниках гражданской войны и великой отечественной войны. Объединение данных Реестра с базами данных таких проектов как портал «Память народа» (13), позволит существенно расширить географию и реализовать социально-экономический потенциал исто- 
рико-культурного и, особенно, военно-мемориального туризма.

Переходя к анализу систематизационной практики в туризме, прежде всего, следует обратиться к базовым реестрам публичного характера.

Особое место в реестровой практике имеет учет субъектов туристской деятельности. В связи с глубокой дифференциацией туроператорской деятельности по направлениям и видам туризма, систематизация данных о туроператорах ведется региональном и федеральном уровнях. При этом в первом случае реестры выступают как системная совокупность механизма правового регулирования туристской деятельности и имеют сугубо императивный характер. Во втором, реестровый учет ведется по инициативе органов исполнительной власти субъектов РФ и направлен исключительно на решение экономических задач в сфере развития регионального туризма.

Остановимся на некоторых примерах федеральных реестров. Для обеспечения правового контроля за деятельностью туроператоров в редакцию федерального закона «Об основах туристской деятельности в РФ» от 05.02.2007 был введен в действие новый специальный юридический инструмент - Единый федеральный реестр туроператоров. Реестровая практика по Единому федеральному реестру туроператоров возложена на Ростуризм (28).

Информация, передаваемая в реестр и предоставляемая в форме госуслуги позволяет субъектам туристских отношений избежать потенциальных имущественных, моральных и физических рисков. В связи с указанным, следует отметить, что не меньшее значение для всех участников туристских отношений имеет и реестр туроператоров, размещенный на сайте Ассоциации «Объединение туроператоров в сфере выездного туризма «Турпомощь» (далее - Ассоциация «Турпомощь»). Как и ЕФРТ реестр Ассоциации «Турпомощь» выполняет роль одного из важнейших императивных средств правового регулирования туристской деятельности (48). Аналогичные задачи решает размещенный на сайте Ассоциации «Турпомощь» реестр турагентств (16). Этот реестр стал формой адаптации розничного сектора туристских посредников к новым условиям в качестве прототипа федерального реестра турагентов, вводимого в 2022 г. (30; 47). Не менее важное значение в рамках обеспечения повышения качества, развития прозрачного и конкурентоспособного рынка туристско-экскурсионных услуг имеет процесс перехода к обязательной аттестации экскурсоводов и формирование соответствующих реестров аттестованных экскурсоводов, гидов и проводников, намеченный на вторую половину 2022 г. (29; 45).
Проанализированная федеральная реестровая практика в туризме, имеет исключительно обязательный характер и направлена на обеспечение безопасности и защиту интересов потребителей и участников туристских отношений. Однако формирование федеральных реестров субъектов туристской деятельности представляет лишь часть создаваемой в России системы электронного информационного учета в туризме. Так, для защиты коммерческих и потребительских интересов участников туристских отношений Министерством культуры РФ был введен в действие специализированный портал (35). Основное содержание данного сайта включает электронную форму единого информационного окна «Федерального перечня классифицированных гостиниц и иных средств размещения, горнолыжных трасс и пляжей, аккредитованных организаций и органов по аккредитации в субъектах Российской Федерации». Аналогичные задачи призван обеспечивать федеральный «печень санаторно-курортных комплексов», формирование и ведение которого обеспечивает Минздрав РФ $(26 ; 31)$. Вместе с тем, следует отметить, что этот перечень содержит лишь минимальную идентификационную информацию об объектах учета (14).

Основное направление комплексной работы и специальная форма реализации популяризационных задач систематизации туристских ресурсов нашли выражение в создании Ростуризмом «автоматизированной информационной системы комплексной поддержки развития внутреннего и въездного туризма в РФ»- АИС «Туризм» (22). Основной задачей АИС «Туризм» в сфере продвижения определена «консолидация (интеграция) информационных ресурсов отрасли в Интернете и создание национального туристического портала». Для ее решения была разработана подсистема АИС «Туризм» «Национальный туристический портал Russia.travel» (1).

Согласно Положению о подсистеме АИС «Туризм» «Национальный туристический портал», она представляет собой информационно-сервисный мультимедийный централизованный интернет-ресурс, направленный, прежде всего, на обеспечение доступа всех заинтересованных лиц к сведениям о туристских ресурсах и туристской индустрии Российской Федерации (29).

В рамках реализации публичной региональной систематизационной практики федерального значения в последние годы также были созданы специализированные цифровые ресурсы учетного характера. Так, по поручению координационного совета Федеральной программы развития внутреннего и въездного туризма был создан портал - «Унифицированный туристский паспорт» (40). Данный проект является сводной элек- 
тронной базой туристских ресурсов и объектов туристской индустрии субъектов РФ. Согласно основным задачам проекта была сформирована его тематическая структура: статистические данные; информационные данные; описательные данные; маркетинговая информация. Кроме того, туристская информация разделана на специальные блоки по характеру (целям) потребителей.

Глобальным информационным ресурсом, объединившим публичных и частных участников туристских отношений, является «Система обмена туристской информации» (СОТИ). СОТИ создавалась как цифровая площадка для объединения усилий публичных органов, общественных организаций и бизнеса в задачах по «продвижению и реализации туристских продуктов регионов на внутреннем и международном туристском рынке» (37). Задачи СОТИ обусловили состав ее участников: региональные ТИЦы, средства размещения, субъекты турдеятельности и органы исполнительной власти.

Реестровая деятельность публичных субъектов объективно базируется на специфических формах систематизации ресурсов на муниципальном уровне. Однако учитывая низкую значимость муниципальных территорий в большинстве региональных туристских экономик России, данный уровень систематизационной деятельности не нашел должного нормативного регулирования. В частности, В Волгоградской области это нашло выражение в создании туристских паспортов муниципальных районов, сформированных в рамках общей туристской паспортизации субъектов России. Отсутствие нормативного регулирования муниципальной систематизации предопределило различие в подходах к выбору форм и структуры туристских паспортов (11). Неопределенность форм объективно снижает эффективность и значимость муниципальной реестровой практики.

Однако, учитывая роль систематизационной практики в определении туристского потенциала, следует отметить, что наиболее полную качественную и количественную статистическую информацию о потенциале конкретной туристской территории можно получить именно на муниципальном уровне. Кроме того именно такое направление сбора статистической информации позволит выделить уникальные и малоизвестные ресурсы, обеспечить их продвижение на разных уровнях, а также определить наиболее актуальные подходы к формированию устойчивого развития территориального туризма.

Составленные по унифицированной критериальной форме реестры туристских ресурсов муниципальных образований, направленные на формирование инвентаризационных таблиц, карт туристского потенциала территории, помогут сформировать туристско-рекреационный каркас территории субъекта, выделить приоритетные виды туризма, разработать систему уникальных туристских маршрутов на основе статистических данных всей совокупности муниципальных ресурсов. Такая организация территориальной систематизации туристских ресурсов в институциональной форме создаст благоприятные условия для выстраивания горизонтальной системы управления туристской территорией с характерным оперативным механизмом принятия решений актуальной как в вопросах обеспечения развития туристкой инфраструктуры, так и с точки зрения управления качеством турпродукта территории.

Стратегически наибольшее значение для развития внутреннего и въездного организованного и самостоятельного туризма в регионах Российской Федерации имеет создание реестров туристских ресурсов субъектов. Прежде всего этот уровень реестровой деятельности актуализируется необходимостью упорядочения информации об обширных и разнообразных туристских ресурсах субъектов (39). Безусловно, институционально организованная и формально определенная реестровая деятельность позволяет не только определить туристский потенциал территории, или обеспечить эффективное продвижение регионального туристского продукта. Она также направлена на обеспечение эффективного программно-планового развития туризма в субъекте. Очевидно именно в этой связи задача по формированию реестров туристских ресурсов задекларирована в нормах, утвержденной в 2019 г. государственной программе «Развитие туризма в Волгоградской области» на период 2019-2025 г. Программа содержит перечень целого ряда мероприятий информационного учетно-систематизационного характера (17).

Отметим, что в настоящее время согласно ст. 5 действующего закона Волгоградской области о развитии туризма к полномочиям органов исполнительной власти в рамках систематизационной деятельности в туризме, отнесены: участие в информационном обеспечении туризма, установление порядка создания и ведения реестра туристских ресурсов, расположенных в Волгоградской области (6).

Органом исполнительной власти в сфере туризма в Волгоградской области определен соответствующий профильный Комитет по развитию туризма. Очевидно, что для реализации упомянутых норм закона Волгоградской области «О развитии туризма в Волгоградской области» именно к полномочиям этого Комитета 
отнесено информационное обеспечение сферы туризма, включающее в себя «ведение мониторинга использования туристских ресурсов, установление порядка формирования и ведения реестра туристских ресурсов, расположенных в Волгоградской области» (19).

В подчинении комитету находится ГАУ Волгоградской области «Агентство развития туризма». Согласно п. 2.4 устава АРТ ВО задачи по реестровой систематизационной практике в Волгоградской области нашли выражение в определении специальных видов деятельности Агентства (24). Анализ реестровой деятельности АРТ ВО показал, что ведется она без соответствующего нормативно-правового обеспечения (34). Содержание и формы реестров не получили должного регулирования и создаются, очевидно, с учетом ведения статистической деятельности, а не задач специального туристского профиля, определенных уставом учреждения.

Следует отметить, что такой неопределенный подход к реестровой практике в современных условиях представляется уже как единичный случай. Проведенный системный анализ показал обеспечение в той или иной форме нормативного регулирования систематизационной деятельности в сфере туристских ресурсов во всех субъектах России. Отметим, что в ряде случаев правовое регулирование носит исключительно общий, устанавливающий характер и ограничивается императивной нормой о закреплении функции по ведению реестров туристских ресурсов за региональным органом исполнительной власти в сфере туризма. Вместе с тем, в большинстве субъектов, представляющих развитые туристские территории, получило развитие специальное нормативное регулирование реестровой деятельности. При этом в ряде субъектов нормотворцы не ограничиваются регламентацией форм «реестров». Нормативному регулированию подвергаются вопросы классификации и оценки туристских ресурсов, определения режима охраны, допустимой нагрузки, условий доступа к ресурсам, формирования кадастра туристских территорий и соответствующих направлений контроля (7).

Обобщая результаты проведенного исследования, отметим, что в современной практике практически повсеместно реестровый учет на уровне субъектов ориентирован не только на ресурсы территории, направленные на удовлетворение туристско-экскурсионных потребностей туристов/экскурсантов. Очевидно, ориентируясь на перспективное развитие самодеятельного туризма как одного из приоритетных направлений, а также на обеспечение общих и специальных интересов туристов как потребителей, особое внимание уделяется систематизации субъектов туристской деятельности и объектов туриндустрии. Итак, приведем несколько примеров.
Учитывая роль реестровой деятельности как фактора, оказывающего влияние на развитие туризма не только в субъекте, но и на уровне регионов и федеральном уровне, заслуживают внимания практики учета в сфере туризма в форме АИС/ЕИС, адаптированной к интеграции в федеральную АИС «Туризм». В частности, речь идет о ЕГИС «Реестр субъектов и объектов туристской индустрии и туристских ресурсов Краснодарского края». Согласно Порядку формирования и ведения реестра «формирование и ведение Единого реестра осуществляется министерством курортов, туризма и олимпийского наследия Краснодарского края» (25).

Основываясь на нормативном установлении реестр субъектов туристской деятельности, объектов туристской индустрии и туристских ресурсов Краснодарского края должен состоять из следующих разделов: «Санаторно-курортные и оздоровительные организации»; «Гостиницы и иные средства размещения (за исключением кемпингов)»; «Туристские организации»; «Кемпинги»; «Пляжи»; «Лечебно-оздоровительные местности (курорты) краевого и местного значения»; «Объекты туристского показа»; «Яхтенные порты (марины)»; «Туристские маршруты» (25, ст. 1.3). Как видим, в основном реестры посвящены рекреационным ресурсам, что определяется спецификой туристского потенциала региона.

Важно отметить, что нормативному определению подлежат также и формы паспортов объектов (субъектов) туристской индустрии и туристских ресурсов Краснодарского края (25). Каждая форма содержит информацию, разделенную на три блока: информация о заявителе, информация об объекте, а также дополнительная информация. Отметим, что содержание реестра практически не претерпело изменений с 2012 года, в сравнении с практикой на основе постановления губернатора Краснодарского края от 04.10.2012 (18). Вместе с тем, следует отметить подчеркнутый принцип оперативности обновления информации, согласно которому все изменения данных реестра должны производиться в течение пяти дней. Кроме того, безусловно положительно следует отметить интеграцию реестра в форму ЕГИС «Курорты Краснодарского края». При этом, наполнение информационной системы происходит исходя из более глубокой классификации объектов и субъектов туристской индустрии (4).

В XМАO - Югра определены цели ведения реестра с учетом публичных и частных интересов участников туристских отношений: обеспечение единого учета туристских ресурсов и организаций туристской индустрии субъекта; предоставление туристам (экскурсантам) необходимой информации, обеспечивающей компетентный выбор в сфере туризма; совершенствование 
управления туристскими ресурсами; обеспечение эффективности мониторинга использования, сохранения и восстановления туристских ресурсов (23). Такой широкий спектр актуальных целей реестровой практики обусловил необходимость расширенной классификации объектов и увеличенный список признаков объектов реестрового учета.

Поскольку формируемый реестр изначально получил статус единой информационной базы, содержащей сведения о туристских ресурсах и организациях туристской индустрии АО Югры, он также реализуется в электронной форме, размещенной на специальном сайте. Электронный реестр туристских ресурсов и организаций туристской индустрии Югры выстроен по административно-территориальному принципу, в структуру которого введены разделы задекларированного в Постановлении реестра.

Следует отметить, что унифицированное и схематичное построение электронного реестра, выраженное в стремлении сохранить классификацию объектов учета неизменной, как представляется, является необязательным для разных муниципальных образований (33).

Постановление Правительства Республики Хакасия, также как и в Постановление Правительства ХМАО Югры определяет цели ведения реестра с учетом интересов широкого круга участников туристских отношений (20, ст. 1.3). При этом для достижения поставленных целей Порядком нормативно закрепляется ведение реестра в электронной форме и бумажном носителях (20, ст. 1.5). Согласно Порядка формирования и ведения реестра туристских ресурсов на территории Республики Хакасия определяется приемлемая классификация объектов учета в рамках трех разделов структуры реестра: 1) природные; 2) объекты культурного наследия; 3) социально-культурные объекты.

Электронная форма реестра размещена на сайте Государственного комитета по туризму Республики Хакасия в разделе «Туриндустрия. Отметим, что в настоящий момент электронный реестр содержит лишь часть разделов реестра, определенных Порядком формирования и ведения. В частности, из раздела I размещены исключительно государственные природные заповедники и заказники (3).

Интерес потребителей защищают и реестры Нижегородской области. Основная задача реестровой деятельности в Нижегородской области - информационное обеспечение, а также нормативное обеспечение контроля качества. Очевидно, именно в этой связи в реестр субъектов входят не только турфирмы, но и экскурсоводы, инструкторы и т.д. Ведение рее- стров субъектов туристской индустрии и туристских ресурсов возложено на Правительство нижегородской области $(8$, ст. 5).

Подводя итоги исследования, следует отметить, что анализ деятельности по систематизации в сфере туризма на федеральном уровне позволил выявить в качестве приоритетного правового средства использование смешанных и императивных методов правового регулирования. Характеристика систематизационной практики в зависимости от субъекта позволили выделить цели и сущностное содержание соответствующей практики в сфере популяризации туризма посредством информационного обеспечения, а также в сфере защиты предпринимательских и потребительских интересов участников туристской деятельности.

Выявленные в этой связи базовые функции реестровой деятельности на федеральном уровне стали основанием утверждения основных форм реализации систематизационной практики. В этой связи особое значение имеет то, что императивное нормативное определение структуры и содержания этих форм введено относительно реестров, направленных на обеспечение безопасности туристских отношений в целом, включая частные и публичные интересы.

Вместе с тем специальные формы систематизации, введенные в туристский маркетинг как комплексные средства продвижения российского турпродукта, реализуются структурно и композиционно с учетом необходимости популяризации туристских территорий на основе принципа аттрактивности и задач национального маркетплейса.

Подводя итоги анализа правового регулирования систематизационной деятельности в туризме соответствующими органами субъектов России, необходимо отметить, что региональная практика учета ресурсов в форме информационных систем с элементами кадастров или реестров, очевидно, направлена на интеграцию информации о потенциале и индустрии территорий в АИС «Туризм». Учитывая значение этой системы (ее подсистем) в вопросах продвижения турпродукта территории, можно предположить ее содержательные элементы становятся императивными установками для региональной практики нормативного регулирования систематизационной деятельности как в вопросах классификации турресурсов и объектов туриндустрии, так и в вопросах архитектоники реестров.

Вместе с тем, анализ практики правового регулирования систематизационной деятельности ряда субъектов позволят выделить ее системные недостатки. Прежде всего следует выделить неотрегулированность вопро- 
са наличия, а также форм и структуры паспортов туристских ресурсов. Эти же аспекты систематизационной деятельности требуют нормативного определения проблемы форм самих реестров туристских ресурсов. Указанные недостатки реестровой практики не являются исчерпывающими. Однако учитывая результаты исследования можно предположить, что основные проблемы могут быть разрешимы в рамках комплексного анализа систематизационных практик субъектов всех уровней с учетом использования практик частно-правовой, а также смешанной по природе реестровой деятельности.

Таким образом, следует подчеркнуть, что конкретизированная нами экономическая и правовая сущность реестровой деятельности объектов туриндустриии и туристских ресурсов определяет ее безусловное зна- чение в качестве актуального механизма обеспечения устойчивого развития туристского сектора экономики. Сложившаяся практика правового регулирования правового регулирования и управления систематизационной деятельностью позволяет наметить приоритетные векторы ее развития.

\section{Примечание}

Исследование выполнено при финансовой поддержке РФФИ и Администрации Волгоградской области в рамках научного проекта № 19-49-340007 p_a

Acknowledgement. «The reported study was funded by RFBR and the government of Volgograd region according to the research project № 19-49-340007».

\section{ЛИТЕРАТУРА}

1. Национальный туристический портал Russia.travel [Электронный ресурc]. URL: www.russia.travel) (дата обращения — 23.04.2021 г.)

2. Вапнярская, О.И., Харитонова, Т.В., Кривошеева, Т.М. Тенденции в практике менеджмента туристской дестинации // Вестник Ассоциации вузов туризма и сервиса. 2015. Т. 9. № 1. С. 21-28.

3. Государственные природные заповедники и заказники // Государственный комитет по туризму Республики Хакасия [Электронный ресурс]. URL: http://gkt.r-19.ru/travel-industry/gosudarstvennye-prirodnye-zapovedniki-i-zakazniki.html) (дата обращения — 23.04.2021 г.)

4. Единая государственная система «Реестр субъектов и объектов туристской индустрии и туристских ресурсов Краснодарского края» [Электронный ресурс]. URL: http://egis.kurortkuban.ru/ (дата обращения - 23.04.2021 г.)

5. Жарников, В.Б., Конева, А.В. 0 проблеме кадастра туристских ресурсов и его основном содержании // Вестник СГУГиТ. 2017. Вып. 22. № 4. С. 148-155

6. Закон Волгоградской области № 90-ОД от 16 июля 2018 «0 развитии туризма в Волгоградской области» // Официальный интернет-портал правовой информации. URL: http://www.pravo.gov.ru, 17.07.2018; Волгоградская правда. 27.07.2018. N85.

7. Закон Ленинградской области № 73-03 «0 туристской деятельности на территории Ленинградской области» (с изменениями на 15 октября 2009 года) (утратил силу на основании Закона Ленинградской области от 20.05.2019 N39-03) // Вестник Правительства Ленинградской 0бласти. 30.04.98. ⒊

8. Закон Нижегородской области № 8-3 0 туристской деятельности на территории Нижегородской области (с изменениями на 2 октября 2019 года) // Нижегородские Новости. 21.02.2008. № 33 (3925); Правовая среда. № 13(896)

9. Кузнецова, Н.Ф. Информационный ресурсы как инструмент продвижения на рынок туристской дестинации на примере Республики Хакасия // Азимут научных исследований: экономика и управление. 2017. Т. 6. № 3 (20). С. 215-218

10. Лебедева, Т.Е., Шкунова, А.А., Слаутина, М.С. Продвижение на рынке туризма: новое решение // Инновационная экономика: перспективы развития и совершенствования. 2018. № 5 (31). с. 81-85.

11. Муниципальные образования. Туристские паспорта // Государственное автономное учреждение Волгоградской области «Агентство развития туризма» (ГАУ В0 «Агентство развития туризма»): официальный сайт [Электронный ресурс]. URL: http://www.turizm-volgograd.ru/index.php?option=com_ content\&view=category\&layout=blog\&id=34\&ltemid=53 (дата обращения -23.04 .2021 г.).

12. Объединение туроператоров в сфере выездного туризма «Турпомощь»: официальный сайт. [Электронный ресypc]. URL: https://www.tourpom.ru/ (дата обращения - 23.04.2021 г.).

13. Память народа: Поиск документов о Героях Войны [Электронный ресурс]. URL: https://pamyat-naroda.ru/ (дата 0бращения — 23.04 .2021 г.)

14. Перечень санаторно-курортных учреждений (государственной, муниципальной и частной систем здравоохранения) // 0ткрытые данные. Министерство здравоохранения Российской Федерации: официальный сайт https://minzdrav.gov.ru/opendata/7707778246-perechensanatornokurortnyhuchrezhd enij/visual (дата обращения - 23.04.2021 г.)

15. Подкопаев, О.А. К вопросу об оценке туристского потенциала регионов // В сборнике: Национальное культурное наследие России: региональный аспект. Материалы III Всероссийской научно-практической конференции. Под редакцией С.В. Соловьевой. 2015. С. $213-220$.

16. Положение о порядке формирования и ведения сведений о Турагентах (Реестра) Ассоциацией «Турпомощь» [Электронный ресурс] // 0бъединение туроператоров в сфере выездного туризма «Турпомощь»: официальный сайт. https://www.tourpom.ru/page/turagentstvam (дата обращения 23.04.2021 г.).

17. Постановление Администрации Волгоградской области от 09.04.2019 № 168-п «0б утверждении государственной программы Волгоградской области «Развитие туризма в Волгоградской области»» (с изменениями на 29 декабря 2020 года) // Официальный интернет-портал правовой информации. URL: http://pravo.gov.ru, 12.04.2019. 
18. Постановление главы администрации (губернатора) Краснодарского края от 04.10 .2012 N1162 « 06 утверждении Порядка формирования и ведения реестра субъектов и объектов туристской индустрии и туристских ресурсов Краснодарского края» (утратило силу) // Кубанские новости. 17.10.2012. N200.

19. Постановление Губернатора Волгоградской области от 25.10 .2018 № 703 «0б утверждении Положения о комитете по развитию туризма Волгоградской области» // Официальный интернет-портал правовой информации. URL: http://www.pravo.gov.ru, 29.10.2018; Волгоградская правда. 02.11.2018. N127/

20. Постановление Правительства Республики Хакасия № 436 от 15 июля 2011 «0б утверждении Порядка формирования и ведения реестра туристских ресурсов на территории Республики Хакасия» (с изменениями на 29 июля 2020 года) // Вестник Хакасии. 21.07.2011. N66.

21. Постановление Правительства РФ 747 «06 утверждении Правил создания и функционирования единой информационной системы электронных путевок, структуры единой информационной системы электронных путевок и условий предоставления содержащейся в единой информационной системе электронных путевок информации (с изменениями на 23 ноября 2020 года)» // Собрание законодательства Российской Федерации. N25. 24.06.2019. ст. 3254; 0фициальный интернет-портал правовой информации www.pravo.gov.ru, 17.06.2019, N0001201906170015; Портал информационной системы «Электронная путевка» // Ростуризм. URL: https://tourism.gov.ru/operators/elektronnaya-putevka/.

22. Постановление Правительства РФ от 02.08.2011 N644 (ред. от 18.12.2014) «0 федеральной целевой программе «Развитие внутреннего и въездного туризма в Российской Федерации (2011-2018 годы)»» // Собрание законодательства Российской Федерации. 22.08.2011. N34. ст. 4966.

23. Постановление Правительства Ханты-Мансийского автономного округа — Югры № 545-п от 13 декабря 2013 г. «0 реестре туристских ресурсов и организаций туристской индустрии Ханты-Мансийского автономного округа — Югры» (с изменениями на: 03.03.2017) // Собрание законодательства ХМА0-Югры. 15.12.2013. N12 (часть 1). с. 1537.

24. Приказ комитета по развитию туризма Волгоградской области № 20-0Д от 11 декабря 2018 об утверждении «Устава ГАУ В0 «Агентство развития туризма» // Государственное автономное учреждение Волгоградской области «Агентство развития туризма» (ГАУ В0 «Агентство развития туризма»): официальный сайт [Электронный ресурc]. URL: http://www.turizm-volgograd.ru/images/\%D0\%A3\%D0\%A1\%D0\%A2\%D0\%90\%D0\%92_\%D0\%93\%D0\% 90\%D0\%A3_\%D0\%92\%D0\%9E_\%D0\%90\%D0\%A0\%D0\%A2.pdf (дата обращения-23.04.2021 г.).

25. Приказ Министерства курортов, туризма и олимпийского наследия Краснодарского края № 129 от 09 июля 2018 «06 утверждении «Порядка формирования и ведения реестра субъектов, объектов туристской индустрии и туристских ресурсов Краснодарского края»» // Министерство курортов, туризма и олимпийского наследия Краснодарского края официальный сайт [Электронный ресурc]. URL: https://kurort.krasnodar.ru/documents/ nра/40034 (дата обращения - 23.04.2021 г.).

26. Приказ Минтруда России N301н, Минздрава России N449н от 10.07.2013 «06 утверждении перечня санаторно-курортных учреждений (государственной, муниципальной и частной систем здравоохранения), в которые предоставляются при наличии медицинских показаний путевки на санаторно-курортное лечение, осуществляемое в целях профилактики основных заболеваний граждан, имеющих право на получение государственной социальной помощи» // Российская газета. 16.08.2013. N181

27. Приказ Ростуризма N159-Пр-15 от 15.04.2015 “06 утверждении Положения о подсистеме AИС «Туризм» «Национальный туристический портал»” // Федеральное агентство по туризму: официальный сайт [Электронный ресурc]. URL: // https://tourism.gov.ru/contents/turism_v_rossii/vnimaniyuorganov-ispolnitelnoy-vlasti-subektov-rossiyskoy-federatsii-v-sfere-turizma/o-natsionalnom-turistskom-portale?sphrase_id=131179 (дата 0бращения — 23.04.2021 г.).

28. Приказ Ростуризма от 09.01.2019 N2-Пр-19 «06 утверждении Административного регламента по предоставлению Федеральным агентством по туризму государственной услуги по формированию и ведению единого федерального реестра туроператоров»

29. Проект № 864169-7 «0 внесении изменений в Федеральный закон «0б основах туристской деятельности в Российской Федерации» в части правового регулирования деятельности экскурсоводов (гидов), гидов-переводчиков и инструкторов-проводников» // Объекты законотворчества. Система обеспечения законотворческой деятельности.—URL: https://sozd.duma.gov.ru/bill/864169-7 (дата обращения — 23.04.2021 г.)

30. Проект № 877880-7 «0 внесении изменений в Федеральный закон «06 основах туристской деятельности в Российской Федерации»» // 0бъекты законотворчества. Система обеспечения законотворческой деятельности.—URL: https://pravo.ru/news/230148/ (дата обращения — 23.04 .2021 г.).

31. Распоряжение Правительства РФ 2852-р «06 утверждении плана мероприятий по реализации Стратегии развития санаторно-курортного комплекса Российской Федерации (с изменениями на 3 июня 2020 года)» // Собрание законодательства Российской Федерации. 09.12.2019. N49 (ч.VI). ст. 7166; Официальный интернет-портал правовой информации www.pravo.gov.ru, 03.12.2019, N0001201912030016

32. Распоряжение Правительства РФ от 20.09.2019 N2129-р (ред. от 23.11.2020) «0б утверждении Стратегии развития туризма в Российской Федерации на период до 2035 года» // Официальный интернет-портал правовой информации http://pravo.gov.ru, 23.09.2019, Собрание законодательства РФ. 30.09.2019. N39. ст. 5460

33. Реестр туристских ресурсов и организаций туристской индустрии Югры [Электронный ресурс]. URL: https://tourism.admhmao.ru/reestr-turistskikhresursov-i-organizatsiy-turistskoy-industrii-yugry/ (дата обращения - 23.04.2021 г.)

34. Реестры // Государственное автономное учреждение Волгоградской области «Агентство развития туризма» (ГАУ В0 «Агентство развития туризма»): официальный сайт [Электронный ресурс]. URL: http://turizm-volgograd.ru/index.php?option=com_content\&view=article\&id=58\&ltemid=44 (дата 06ращения - 23.04.2021 г.)

35. Сведения из Единого государственного реестра объектов культурного наследия (памятников истории и культуры) народов Российской Федерации. URL: https://opendata.mkrf.ru/opendata/7705851331-egrkn/ (дата обращения — 23.04.2021 г.)

36. Свитин, В.А., Матасева, В.В., Тишкович, 0.В. Формирование бренда территории как имиджевого ресурса развития сельской местности // Вестник Белорусской государственной сельскохозяйственной академии. 2012. № 3. С. 104-109. 
37. Система обмена туристской информации [Электронный ресурc]. URL: http://nbcrs.org/ (дата обращения — 23.04 .2021 г.).

38. Специализированный портал «Федеральный перечень туристских объектов» [Электронный ресурc]. URL: https://xn-—7sba3acabbldhv3chawrl5bzn. xn — p1ai/displayAccommodation/search (дата обращения — 23.04.2021 г.)

39. Унифицированный туристский паспорт «Волгоградская область» // Унифицированный туристский паспорт [Электронный ресурс]. URL: http://utp. nbcrs.org/ (дата обращения - 23.04.2021 г.)

40. Унифицированный туристский паспорт [Электронный ресурc]. URL: http://utp.nbcrs.org (дата обращения — 23.04 .2021 г.).

41. Учет и контроль территориальных туристско-рекреационных ресурсов // Территориальные туристско-рекреационные системы. Дыбаль М.А., Викторова Е.В., Шарафанова Е.Е. Санкт-Петербург, 2016. С. 57-77.

42. Ушакова Е.О., Цой М.Е. Разработка методического подхода к оценке туристско-рекреационного потенциала региона // Сервис в России и за рубежом. 2017. T. 11. № 4 (74). С. 18-34.

43. Федеральный закон от 10.01.2002 N7-Ф3 «06 охране окружающей среды» (ред. 0т 09.03.2021) // Российская газета. N6. 12.01.2002; Парламентская газета. N9. 12.01.2002; Собрание законодательства РФ. 14.01.2002. N2. ст. 133.

44. Федеральный закон от 14.03.1995 N33-Ф3 «0б особо охраняемых природных территориях» (с изменениями на 30 декабря 2020 года)» // Собрании законодательства Российской Федерации. 20.03.1995. ⒓ ст. 1024; Российской газете. 22.03.1995. № 57.

45. Федеральный закон от 20.04.2021 № 93-Ф3 «0 внесении изменений в Федеральный закон «06 основах туристской деятельности в Российской Федерации» в части правового регулирования деятельности экскурсоводов (гидов), гидов-переводчиков и инструкторов-проводников» Официальный Интернет-портал (www.pravo.gov.ru). 20.04.2021. Номер опубликования: 0001202104200044.

46. Федеральный закон от 23.02.1995 N26-Ф3 «0 природных лечебных ресурсах, лечебно-0здоровительных местностях и курортах» (ред. от 08.12.2020) // Собрание законодательства РФ. 27.02.1995. N. ст. 713; Российская газета. N44. 01.03.1995.

47. Федеральный закон от 24.03.2021 № 48-Ф3 «0 внесении изменений в Федеральный закон «06 основах туристской деятельности в Российской Федерации» // Официальный Интернет-портал (www.pravo.gov.ru). 24.03.2021. Номер опубликования: 0001202103240039.

48. Федеральный закон от 24.11.1996 N132-Ф3 (ред. от 09.03.2021) «06 основах туристской деятельности в Российской Федерации» // Собрание законодательства РФ. 02.12.1996. N49. ст. 5491; Российская газета. N231. 03.12.1996.

49. Федеральный закон от 25.06.2002 N73-Ф3 «06 объектах культурного наследия (памятниках истории и культуры) народов Российской Федерации» (ред. от 24.02.2021) // Парламентская газета. N120-121. 29.06.2002; Российская газета. 29.06.2002. N116-117; Собрание законодательства РФ. 01.07.2002. N26, ст. 2519.

50. Arenasa, A.E., Gohb J.M., Uruecac, A. How does IT affect design centricity approaches: Evidence from Spain's smart tourism ecosystem // International Journal of Information Management. 2019. Vol. 45. pp. 149-162.

51. Bydłosz, J., Bieda, A., Parzych, P. The Implementation of Spatial Planning Objects in a 3D Cadastral Model // International Journal of Ge0-Information. 2018. Vol. 7. T. 153. pp. 1-14.

52. Deng, T., Hu, Y., Ma, M. Regional policy and tourism: A quasi-natural experiment // Annals of Tourism Research. 2019. Vol. 74. pp. 1-16.

53. Erislan. Tourist Attraction and the Uniqueness of Resources on Tourist Destination in West Java, Indonesia // Review of Integrative Business and Economics Research. 2016. Vol. 5. Issue 1. pp. 251-266.

54. Kušen, E. Tourism Attraction System // Evolution of Destination Planning and Strategy The Rise of Tourism in Croatia. New York — London. 2017. pp. 119-148.

( ) Золотовский Владимир Алексеевич (zolotovskiy.azi@volsu.ru ).

Журнал «Современная наука: актуальные проблемы теории и практики» 